\title{
Reduction of Fatigue Levels of Workers in the Construction Worker by Consuming Banana Chips with the Vacuum Frying Method
}

\author{
Wina Adalea Christi $^{1, *}$, Ari Suwondo ${ }^{2}$, and Yuliani Setyaningsih ${ }^{2}$ \\ ${ }^{1}$ Student of Magister of Health Promotion, Public Health Faculty, Diponegoro University, Semarang - Indonesia \\ ${ }^{2}$ Lecturers of Magister of Health Promotion, Public Health Faculty, Diponegoro University, Semarang - Indonesia
}

\begin{abstract}
Human life can not be separated from daily activities, where the body needs adjustments for a long time. The body's ability to adjust can be reduced because the body has a threshold value. Fatigue will arise when doing activities with a high workload and within a period of time Fatigue is a condition of decreased physical activity, work motivation, and loss of efficiency and endurance after work activity. The purpose of this study is to prove the effectiveness of giving bananas (Musa Paradisiaca) by vacuum frying to the level of fatigue in Construction workers Quantitative research methods with quasiexperimental design Research variables include: age, years of work, smoking habits, and length of work hours. The results showed that there was a decrease in the level of fatigue of workers after being given bananas with a vacuum frying technique for 10 days. Benefits of buyers This program is to provide input to the work environment in the construction sector to pay attention to alternative supplements that can be consumed by workers to reduce work fatigue. This research is expected to be one of the policies that must be considered by construction companies for the work safety and health of their workers.
\end{abstract}

Keywords: fatigue level; construction work environment; vacuum frying method.

\section{Introduction}

Human life cannot be separated from daily activities. Where in conducting activities, the body has the ability to adjust for a long time. The body's ability to conform in certain circumstances may diminish because the body has a threshold value. Fatigue will arise when conducting continuous activities with high loads and long periods of time [1].

Fatigue can occur due to a mechanism that occurs in the body. While doing physical work, it takes the style and activity of the muscles to gain energy. The energy gained is used by muscles to contraction and relaxation. The primary energy source for muscle movement is Adenosine Triphosphate (ATP). However, the available amount can only be used for contraction within a few seconds. Ongoing activities will drain ATP, causing fatigue.

Muscle fatigue is a muscle failure in maintaining and generating strength or loss of muscle ability to contraction produce strength as well as very slow relaxation of muscles [1]. Muscle fatigue in anaerobic activity occurs due to an activity or high intensity that requires rapid energy in a short period of time [2]. Fatigue is also influenced by micronutrients that are pottpotassium. Potassium is an electrolyte that serves to balance fluid in the body and is responsible for delivering nerve impulses and muscle contractions. The deficiency of polyttpotassium can lead to muscle weakness, causing fatigue [3]. The administration of supplements containing pottpotassium is usually administered in the form of natural supplements such as banana fruit juice [4].

Nutrients that are directly involved in this study are polyttpotassium. The banana Fruit of Ambon contains simple carbohydrates and complex carbohydrates, simple banana carbohydrates namely: fructose, glucose, and sucrose that can provide energy quickly. The complex carbohydrate is a nonstarch polysaccharide that can be used to store muscle glycogen reserves [5].

Working fatigue can occur on any work and can lead to work motivation down, difficulty concentration, reduced alertness, frequent mistakes, injuries, and lead to decreased productivity of work. In addition to decreased work productivity, work fatigue is also fatal and causes a working accident [6]. Interviews conducted against $75 \%$ of the total construction workers, obtained preliminary information that they suffered a subjective complaint in the form of sluggish taste, sleepy, and decreased work ability. In addition, workers also feel aches and pains in the arms, shoulders, and waist. Therefore, work fatigue is an issue that needs to get attention. The purpose of this research to prove the effectiveness of banana fruit giving (Musa Paradisiaca) by vacuum frying method against the level of fatigue in construction workers.

\footnotetext{
* Corresponding author: winadalea 94@yahoo.com
} 


\section{Research Method}

Quantitative research method with quasi experiment. The design used in this study was Pretest Posttest With Control Group Design. Free variables: Banana fruit, variable bound: fatigue. The determination of inclusion criteria includes age, employment, smoking habits, and the length of working hours. Sampling techniques In this study used the purposive sampling method with the subject of construction worker research on the quarry and concrete foundations.

Hypotheses on this research are "there is the influence of banana fruit giving (Musa Paradisiaca) with the technique of Vacuum Frying against fatigue level in construction workers. Previously conducted test normality using Kolmogorov-Smirnov and ShapiroWilk, and test variants using a variant of homogeneity test. Analytical techniques used to determine the difference in fatigue before and after the feeding of bananas (Musa Paradisiaca) In this study is to use statistical test Paired Simple T-Test.

\section{Theories}

\subsection{Fatigue}

Fatigue is a protective mechanism of the body to avoid further damage, so it has been a recovery after a break. Fatigue shows different conditions of each individual, but all of them are subject to loss of efficiency and decreased work capacity and endurance [7]. Fatigue is a subjective feeling. Fatigue is a condition with decreased efficiency and need in working [8].

Working fatigue will decrease performance and increase work error rates. Increased working mistakes will give the opportunity to work accidents in the industry. Static muscular loading if maintained for a long time will result in RSI (Repetition Strain Injuries), namely muscle pain, bones, tendons, and others caused by the type of work that is Recurring (repetitive). In addition, the fatigue characteristic will increase with the length of work done. While the decrease of fatigue (recovery) is gained by providing adequate rest [9].

Depending on the process in the muscles, fatigue is divided into two types, namely: (1) Muscular fatigue or commonly referred to as muscular fatigue is a reduced phenomenon of muscle performance after the physical pressure of a Time. This physical fatigue can lead to a number of unfortunate things such as: the weakening of workforce ability in doing work and increasing errors in performing work activities, thereby affecting work productivity. Symptoms of muscle fatigue can be seen in visible symptoms of the outside or external signs [10]. (2) General fatigue is a tremendous feeling of weary. All activities become disturbed, lack of passion to work both physically and psychic, everything feels heavy and feels "sleepy" [11]. Usually marked decreased willingness to work caused by monotoni, intensity and length of physical work, health status and nutritional conditions [12].

\subsection{Factors Related to Fatigue}

a. Age

The old process comes with reduced working ability due to changes in body tools, cardio-vascular system, and hormonal [13]. With the decrease in the work capability of body tools, this will cause the workforce to become increasingly exhausted.

b. Working Period

Working period has a significant effect on the occurrence of work fatigue, which means that the more mass of work grows then work fatigue will increase. The mass of work leads to constant stress experienced by workers along with the adaptation process. The longer the working period, it will affect the level of work fatigue due to the monotonous level of work that has accumulated over the years [14].

c. Smoking Habits

The longer and higher the frequency of smoking, the higher the level of perceived muscle complaints. It is closely related to the freshness condition of one's body. Smoking habits can lower lung capacity, so the ability to consume oxygen decreases and consequently the level of freshness also decreases. It will be easily exhausted because the oxygen content in the blood is low, the burning of carbohydrates is hindered, there is a pile of lactic acid, and finally occurs fatigue [11].

d. Long Working Time

The level of subjective fatigue complaints before going to work for long working time and longer working time significantly tends to be higher than short working time. Working time for a workforce determines its efficiency and productivity.

\subsection{Vacuum Frying}

Vacuum Frying is a production machine for frying a variety of fruits and vegetables with a vacuum frying. Vacuum frying pan is the proper processing way to produce high-quality fruit chips. To produce a product with good quality in the sense of color, aroma, and taste of the fruit-vegetable unchanged and crunchy temperature setting should not exceed $90{ }^{\circ} \mathrm{c}$ and vacuum pressure between $65-76 \mathrm{~cm} \mathrm{Hg}$.

The working principle of vacuum frying sucks water content in vegetables and fruits with high speed so that the pores of the meat of the fruits do not quickly close so that the moisture content in the fruit can be absorbed perfectly. The working principle by regulating the temperature and vacuum pressure balance is to fry the raw material by lowering the air pressure of the space in the frying room until the boiling point to $50^{\circ}$ to $60^{\circ} \mathrm{C}$. Vacuum frying is superior to the ordinary frying pan. Because with this vacuum frying material that is fried does not change the color, flavor and aroma, high protein content, and durable without preservatives. 


\subsection{Construction Work Environment}

Construction is an activity to build facilities and infrastructure. In the field of architecture or civil engineering, construction is also known as a building or unit of infrastructure in an area or in some areas. In summary, construction is defined as the overall object of the building consisting of parts of the building structure. In general, construction activities are supervised by project managers, design engineers or project architects. These people work inside the office, while field supervision is usually handed over to the project foreman who oversees building workers, carpenters, and other building experts to complete the physique of a construction.

For the successful implementation of construction projects, effective planning is very important. This is related to engineering (design and implementation) of infrastructure that considers environmental impact, budget plan, schedule of project planning and occupational safety and health management (K3), building material availability, logistics, da others. Occupational Safety and Health (K3) is essential to serve as part of the project management process because it concerns many aspects that impact will cause a big loss in the later days. The number of work accidents every year is increasing, it is based on lack of respect $\mathrm{K} 3$ management.

The cause of occupational accidents occurs due to an unsound attitude and behavior of unhealthy workers and unsafe working environment conditions. This is due to some things, namely: not using the appropriate personal protective equipment (PPE), does not follow the prescribed working procedures, does not comply with the established work rules, not careful, and physical conditions the weak but still imposing to work. In the process of implementing the construction project, indicating that the implementation of occupational safety and health (K3) that achieves a good level will be able to prevent the occurrence of work accidents in all its forms.

\section{Result}

The company's construction and renovation services include building and interior design work, building contractors, houses, and other buildings, as well as environmental, channel and safety wall of roads. Construction activities are generally supervised by project managers, civil engineers, and architects. They work inside the office, while the supervision of activities in the field is handed over to the supervisor of the project that oversees building laborers, carpenters, irons, carpenters, electricians, carpenters, and other building experts to complete building construction.

To achieve the target development work on schedule, the company classifies the work sections that can be done outside the project location so that all construction works run smoothly and on time. The number of workers 50 people, work for excavation, installation of the foundation structure, installation of building structures, cutting iron, assembling, and welding are carried out in the field and at the time of construction.

The work has a risk that affects workers, because they work every day for 8 hours (at $08.00-16.00$ ) with a rest period of 1 hour (at 12.00-13.00). The research was conducted on 30 people working part of excavation and foundation preparation of building namely: cutting, welding, assembling, and fitting of construction iron for the foundation of the building.

\subsection{Analysis of Research Variable}

The characteristics of respondents are seen based on: age, employment, smoking habits, and long working hours.

Table 1. Frequency Distribution of Worker Characteristics

\begin{tabular}{|c|c|c|}
\hline $\begin{array}{c}\text { Characteristics of } \\
\text { Respondents }\end{array}$ & Frequency & $\begin{array}{c}\text { Percentage } \\
(\%)\end{array}$ \\
\hline \multicolumn{3}{|l|}{ Age } \\
\hline$\leq 40$ years old & 21 & 70 \\
\hline$>40$ years old & 9 & 30 \\
\hline Total & 30 & 100 \\
\hline \multicolumn{3}{|l|}{ Working Period } \\
\hline$\leq 10$ years & 15 & 50 \\
\hline$>10$ years & 15 & 50 \\
\hline Total & 30 & 100 \\
\hline \multicolumn{3}{|l|}{ Smoking Habit } \\
\hline No Smoking & 2 & 7 \\
\hline Light Smoker & 15 & 50 \\
\hline Moderate Smoker & 13 & 43 \\
\hline Heavy Smokers & 0 & 0 \\
\hline Total & 30 & 100 \\
\hline \multicolumn{3}{|l|}{$\begin{array}{c}\text { Duration of Working } \\
\text { Hours }\end{array}$} \\
\hline Normal & 30 & 100 \\
\hline Above Normal & 0 & 0 \\
\hline Total & 33 & 100 \\
\hline
\end{tabular}

Table 1 shows the frequency distribution of the worker characteristics based on age, gender, and employment can be noted that the working age of most in the age group is $\leq 40$ years of 21 people $(70.0 \%)$. The rest of the age group was $>40$ years 9 people $(30.0 \%)$. The working period of construction workers who have a $<10$-year tenure of 15 people $(50.0 \%)$ and $\geq 10$ years as many as 15 people $(50.0 \%)$. The habit of smoking construction workers consist of: not smoking as much as 2 people $(7.0 \%)$ And a light smoker as many as 15 people $(50.0 \%)$. While the smoker was 13 people $(43.0 \%)$. From the table above, it can be identified that the characteristics of workers mostly in the age group $\leq$ 40 years, male gender, have an average work period of 10 years, and light smokers. 
Table 2. Frequency Distribution of Banana Fruit Feeding by Vacuum Frying Method on Construction Workers

\begin{tabular}{|c|c|c|}
\hline Treatment & Frequency & $\begin{array}{c}\text { Percentage } \\
(\mathbf{\%})\end{array}$ \\
\hline Banana Chips & & 50,0 \\
\hline Land Excavation Field & 15 & 50,0 \\
\hline Concrete Foundation Field & 15 & $\mathbf{1 0 0 , 0}$ \\
\hline Total & $\mathbf{3 0}$ & \\
\hline
\end{tabular}

Table 2 shows the frequency distribution of working characteristics based on the treatment of banana fruit with vacuum frying technique on construction workers mostly given as much as 15 people $(50.0 \%)$ And the remainder were not given as many as 15 people $(50.0 \%)$.

Table 3. Fatigue Frequency Distribution on Construction Workers

\begin{tabular}{|c|c|c|}
\hline Fatigue & Frequency & $\begin{array}{c}\text { Percentage } \\
(\mathbf{\%})\end{array}$ \\
\hline Normal & 20 & 67,0 \\
\hline Light & 6 & 20,0 \\
\hline Medium & 4 & 13,0 \\
\hline Heavy & 0 & 0,0 \\
\hline Total & $\mathbf{3 0}$ & $\mathbf{1 0 0 , 0}$ \\
\hline
\end{tabular}

Table 3 shows the frequency distribution of worker characteristics based on the level of fatigue in construction workers who have normal levels of fatigue of 20 people $(67.0 \%)$, mild fatigue level of 6 people $(20.0 \%)$, and moderate fatigue rate of 4 people $(13.0 \%)$.

\subsection{Analysis of Reduction Fatigue Levels of Construction Workers with Giving Banana Vacuum Frying Method}

One of the main contributors to fatigue is a decrease in glucose during heavy and extended exercise [15]. When exercising, the liver breaks down glycogen into glucose and releases it into the bloodstream into energy [11]. Muscle glycogen decreases $40 \%$ to $90 \%$ during the game where muscle glycogen is the most important substrate for energy production so that it can be associated with the occurrence of muscle fatigue at the end of the activity due to the depletion of glycogen in some muscle fibers [15]. Based on research, carbohydrate doses of 30-60 grams/hour are able to maintain glucose levels and can maintain the level of carbohydrate burning in the body so that fatigue is inhibited up to 30-60 minutes [16].

Fatigue is also influenced by micronutrients, namely Pottasium. Potassium is an electrolyte that functions for fluid balance in the body and is responsible for delivering nerve impulses and muscle contractions. Deficiency so that it will cause fatigue [3]. Provision of supplements containing potassium is usually given in the form of natural supplements such as bananas [4].

Bananas contain a carbohydrate source of $25 \%$ of the total medium size banana (118 grams). The biggest content of banana carbohydrates consists of glucose and fructose, while the other main ingredients are potassium $422 \mathrm{mg} \%$, calcium $8 \mathrm{mg} \%$, and $\mathrm{Fe} 0.5 \mathrm{mg} \%$. In the body, consumption of glucose or fructose can produce large energy production rates of up to one gram per minute. More benefits will be obtained if combined between fructose-glucose or fructose-sucrose so as to produce a greater energy rate of up to 1.3 grams per minute. Other nutrients contained in bananas are vitamin B complex which can help speed up energy metabolism. The combination of nutrients in the form of carbohydrates, vitamins, minerals, and antioxidants in bananas is a good source of nutrients for long duration activities.

Nutrition that is important in this study is potassium. Ambon banana contains simple carbohydrates and complex carbohydrates, simple carbohydrates, bananas, namely: fructose, glucose, and sucrose which can provide energy quickly. Complex carbohydrates are non-polysaccharide which can be used to store muscle glycogen reserves [5]. All types of carbohydrates consumed will be converted to glucose in the body. Giving carbohydrates of $30-60$ grams/hour is able to maintain glucose levels and can maintain the level of carbohydrate burning in the body so that the occurrence of fatigue is inhibited up to 30-60 minutes [16]. Glucose formed will be stored in the bloodstream as blood glucose and as energy reserves in the form of glycogen in the liver and muscles [4].

Potassium is one of the important minerals for the body. This mineral is needed to overcome muscle contractions, regulate fluid rotation, and mineral balance in the body. Potassium also reduces the negative effects of excessive sodium consumption, because the mineral's main function is to help remove excess sodium through urine and sweat. A sufficient amount of oxygen in the muscle will accelerate the decomposition of metabolic waste substances such as lactic acid. The decomposition of lactic acid in metabolism returns to energy through the Cori cycle.

Giving bananas using the vacuum frying method to banana chips is more effective in reducing the fatigue level of construction workers because the nutritional content in 100 grams of banana chips is:

$\begin{array}{ll}\text { Energy } & 519 \mathrm{kkal} \\ \text { Fat } & 33,6 \mathrm{~g} \\ \text { Cholesterol } & 0 \mathrm{mg} \\ \text { Protein } & 2,3 \mathrm{~g} \\ \text { Carbohydrate } & 58,4 \mathrm{~g} \\ \text { Sodium } & 6 \mathrm{mg} \\ \text { Potassium } & 536 \mathrm{mg}\end{array}$

While the nutritional content of 100 grams of bananas without the vacuum frying method is:

$\begin{array}{ll}\text { Energy } & 89 \mathrm{kkal} \\ \text { Fat } & 0,33 \mathrm{~g} \\ \text { Cholesterol } & 0 \mathrm{mg} \\ \text { Protein } & 1,09 \mathrm{~g} \\ \text { Carbohydrate } & 22,84 \mathrm{~g} \\ \text { Sodium } & 1 \mathrm{mg} \\ \text { Potassium } & 358 \mathrm{mg}\end{array}$

From the comparison above, it can be seen that the banana with the vacuum frying method has a greater nutrient content, so it is very effective in reducing the level of fatigue of workers. In this study building, construction workers were given 100 grams of banana 
chips with the vacuum frying method as an additional supplement for 10 days continuously.

Table 4. Construction Worker Fatigue Level after Consuming Banana Chips with Vacuum Frying Method

\begin{tabular}{|c|c|c|}
\hline $\begin{array}{c}\text { Construction Worker } \\
\text { Fatigue Level }\end{array}$ & Frequency & $\begin{array}{c}\text { Precentage } \\
(\mathbf{\% )})\end{array}$ \\
\hline Normal & 9 & 30,0 \\
\hline Light & 19 & 63,0 \\
\hline Medium & 2 & 7,0 \\
\hline Heavy & 0 & 0 \\
\hline Total & $\mathbf{3 0}$ & $\mathbf{1 0 0}$ \\
\hline
\end{tabular}

\section{Note:}

1. Normal Fatigue (reaction time $150,0-240,0$ milli second)

2. Light Fatigue (reaction time $>240,0-<410,0$ milli second)

3. Medium Fatigue (reaction time 410,0-580,0 milli second)

4. Heavy Fatigue (reaction time $>580,0$ milli second)

Table 4 shows that workers who consumed banana chips with the vacuum frying method experienced very high levels of fatigue. Giving banana chips as an additional nutrient is very effective in reducing the level of fatigue of construction workers.

Bananas have health benefits such as: (a) Healthy digestive tract because bananas contain fiber and carbohydrates which help regulate the digestive system of the body. (b) Protect the kidneys, potassium in bananas has good side effects for the kidneys. Bananas have high levels of antioxidant phenolic compounds which play a role in helping to protect the kidneys. (c) Strengthen bones because bananas contain a prebiotic called fructooligosaccharide which allows the body to absorb nutrients more easily. (d) Prevent muscle cramps, bananas are known to contain high potassium which is $400 \mathrm{mg}$ which is needed by nerves and muscle function, and helps prevent muscle cramps. (e) Preventing muscle disorders, potassium plays an important role in muscle contraction. (f) Muscle strength, potassium ensures muscle tissue growth and proper energy utilization. (g) Healthy heart, high amounts of potassium and low sodium is the best food to maintain heart health. (h) Preventing depression.

Providing additional nutrition for construction workers to reduce fatigue will reduce the risk of workplace accidents so that the goals of occupational safety and health (OSH) for construction workers will be well achieved.

\section{Conclusion}

The level of worker fatigue can be reduced by providing additional supplements in the form of banana chips with the vacuum frying method. The nutritional content of banana chips effectively reduces the level of fatigue of building construction workers.

Additional supplements are a matter that must be considered by construction companies as an effort to reduce the level of worker fatigue in occupational safety and health management (K3). This is very important to do in addition to the use of personal protective equipment (PPE) that must be used by workers at work because of additional supplements in the form of banana chips with the vacuum frying method as a nutritional body for the construction field workers.

Bananas have health benefits such as: (a) healthy digestive tract, (b) protect the kidneys, (c) strengthen bones, (d) prevent muscle cramps, (e) preventing muscle disorders, (f) muscle strength, (g) healthy hear, (h) preventing depression.

The results of this study contribute as one of the inputs for construction companies to pay attention to the safety and health of their workers by providing additional supplements. Also, input for the government in making employment related policies for occupational safety and health (OSH) for construction workers.

\section{References}

1. N.R. Septiana, E. Widowati, Hearing Loss Due to Noise, HIGEIA 1(1),73-82 (2007)

2. F. Ferdinand, Ariewibowo, Practical Learning Biology 2, Jakarta: Ministry of National Education Book Center (2009)

3. S. Kumairoh, A. Syauqy, Effect of Giving Banana (Musa Paradisiaca) on Anaerobic Muscle Fatigue in Sepak Takraw Athletes, Diponegoro University (2014)

4. K.C. Miller, Plasma Potassium Concentration and Content Changes after Banana Ingestion in Exercised Men, J. Athl. Train. (2012)

5. L. Sherwood, Human Physiology: from Cell to System 6 edition, Polish Journal of Surgery (2011)

6. P.K. Suma'mur, Community Participation in Communicating, Disseminating and Motivating the Implementation of Occupational Safety and Health, Yogyakarta: Bigraff Publishing (2003)

7. Tarwaka, H.A. Solichul, Bakri, L. Sudiajeng, Ergonomics for Safety, Occupational Health and Productivity, Surakarta: UNIBA PRESS (2004)

8. A.M. Sugeng Budiono, Hiperkes Pillar, Semarang: Diponegoro University (2003)

9. S. Bakhtiar, Biology, Jakarta: Curriculum Center and Opening of the Ministry of National Education (2011)

10. P.K. Suma'mur, Company Hygiene and Safety. Jakarta: Gunung Agung (2006)

11. Hernawati, Lactic Acid Production in Aerobic and Anaerobic Exercise, Department of Biology Education FPMIPA University of Education Indonesia (2011)

12. Tarwaka, Occupational Health and Safety "Management and Implementation of $\mathrm{OSH}$ at Work", Surakarta: Harapan Pres (2008)

13. Suma'mur, Occupational Safety and Accident Prevention, Jakarta: CV. Haji Masagung (2008).

14. R. Firmansyah, A. Mawardi, U. Riandi, Easy and Active Learning Biology 2, Jakarta: Ministry of National Education Book Center (2009)

15. M.A. Irawan, Body Energy Metabolism and Exercise. Sport Science Brief (2007) 
16. C. Chryssanthopoulos, C. Williams, A. Nowitz, Bogdanis, Skeletal Muscle Glycogen Concentration And Metabolic Responses Following A High Glycaemic Carbohydrate Breakfast, Journal of Sport Sciences, 40- 51 (2004) 